\title{
In-vitro antioxidant activities of ocimum gratissimum, vitex doniana, carica papaya and peristrophe bicalyculata using DPPH free radical scavenging activity
}

\begin{abstract}
The ethanol extract of the leaves of Ocimum gratissimum, Vitex doniana, Carica papaya and Peristrophe bicalyculata were assessed for antioxidant activities by the use of 2, 2-diphenyl1-picrylhydrazyl (DPPH) free radical assay. The reducing potentials of these plants were also evaluated. The phytochemical screenings of the medicinal plants were equally carried out. The percentage antioxidant activity values for the plants are: $60.0 \pm 1.05 \%, 60.8 \pm 1.28 \%$, $62.4 \pm 1.28 \%$ and $75.7 \pm 2.60 \%$ for O. gratissimum, V. doniana, C. papaya and P. bicalyculata respectively. These values were dose dependent and statistically significant at $\mathrm{P}<0.05$ (ANOVA). The results indicated that $P$. bicalyculata has the highest antioxidant activity value of $75.7 \pm 2.60 \%$ while $O$. gratissimum has the least value $60.0 \pm 1.05 \%$. The percentage antioxidant activities of the plants were comparable to the standards used, ascorbic acid and $\alpha$-tocopherol anti-oxidant activities which were found to be $86.7 \pm 1.08 \%$ and $97.2 \pm 1.06 \%$ respectively. The reducing potentials of the plants were found to be proportionally correlated to the antioxidant activities of the plants. Phytochemical screenings revealed the presence of flavonoids, saponins, C. glycosides, steroids, alkaloids, tannins, anthraquinones, terpenoids and carbonhydrates in the medicinal plants.
\end{abstract}

Keywords: antioxidant, DPPH, Ocimum gratissimum, Vitex doniana, Carica papaya, Peristrophe bicalyculate
Volume 8 Issue 6 - 2018

\author{
Victor Duniya Sheneni,' Andrew Omachoko \\ Onoja, ${ }^{2}$ Emmanuel Edegbo, ${ }^{3}$ Theophilus \\ Boniface Momoh ${ }^{4}$ \\ 'Department of Biochemistry, Kogi State University, Nigeria \\ ${ }^{2}$ Department of Animal and Environmental Biology, Kogi State \\ University, Nigeria \\ ${ }^{3}$ Department of Microbiology, Kogi State University, Nigeria \\ ${ }^{4}$ Department of Plant Science and Biotechnology, Kogi State \\ University, Nigeria
}

Correspondence: Sheneni Victor Duniya, Department of Biochemistry, Faculty of Natural Sciences, Kogi State University, PMB 1008,Anyigba, Nigeria, Tel +234-8033519009,

Email shenenevictor@gmail.com

Received: September 24, 2018 | Published: November 09, 2018

\section{Introduction}

Chemical compounds with unpaired electrons in the body act as oxidants, they are generally very reactive and are capable of causing oxidative damage to biological molecules such as proteins, lipids, and also DNA, which subsequently leads to mutation. ${ }^{1}$ Free radicals play a crucial role in human health. The effect of free radical reactions in the body has been implicated in the etiology and pathogenesis of chronic diseases that are life threatening such as cancer, hypertension, cardiac infarction, arteriosclerosis, diabetes etc. Compounds that inhibit or delay the hydrolysis of other molecules by preventing the initiation or propagation of hydrolyzing chain reactions caused by oxidants are called antioxidants. ${ }^{2}$ Pharmacological functions such as anti-mutagenicity, anti-carcinogenicity, anti-aging etc are gotten from the pharmacological properties that originate from antioxidant activities. ${ }^{3,4}$ The most important oxidants in the body are the reactive oxygen and nitrogen species, such as super oxide, hydrogen peroxide and nitric oxide radicals. Cellular and metabolic processes are responsible for generating most of the free radicals in the body; however, they can also come from external sources such as exposure to ionizing radiations, injury, oxidative drugs, pollutants, etc. Due to the constant tendency to obtain an electron from other molecules, thus, their highly reactive nature, free radicals cause damage to cells and tissues when there is excessive production and leakage from their site of origin. DPPH, diphenyl-1-picrylhydrazyl radical scavenging activity assay has been widely used for antioxidant screening of fruit and vegetable juices or extracts. ${ }^{5}$ DPPH is a stable free radical that is hydrolyzed to DPPH-H, prior to reaction with antioxidant, which as a result, decreases its absorbance and its natural purple colour changes to yellow. The degree of discoloration shows how potent the scavenging power of the antioxidant compound or extract is, in terms of the ability to give out hydrogen. The scavenging reaction between $\mathrm{DPPH}$ and an antioxidant (A-H) can be represented as follows;

$$
\mathrm{DPPH}+(\mathrm{A}-\mathrm{H})=\mathrm{DPPH}-\mathrm{H}-(\mathrm{A})
$$

Studies have shown that natural antioxidants, especially the flavonoids, are beneficial to human health as they show a broad range of pharmacological properties such as anti-ischemic, anti-allergic, antibacterial, antiviral, anti-inflammatory, vasodilatory and antiproliferative activities. ${ }^{3}$ The antioxidant activities of several plant materials have been reported. ${ }^{6-11}$ Ocimum gratissimum popularly referred to as African basil in English, is an herbaceous perennial plant that has a woody stem, although its actual origin is unknown, the plant can be found naturally in many regions. Ocimum is a genus of about six species of flowering plants in the family lamiaceae (labiate). Ocimum gratissimum is locally called 'effinrin-nla' by the Yorubas, 'nchu-anwu' by the Igbos, while in the northern part of Nigeria; the Hausas call it 'daidoya'. ${ }^{12}$ The leaf has a characteristic pleasant aroma which is responsible for its name 'Scent leaf', and hence, it's use as spice and condiments in cooking. The whole plant is used in folklore medicine and as insect repellant. ${ }^{13}$ Vitex doniana is a very popular plant used in traditional medicine in Nigeria. They belong to the family of verbenaceae, the local Nigerian names include; dinya (Hausa and Igala), Ucha-koro (Igbo) and Orin-ola (Yoruba). The plant has an average height of about $20-25 \mathrm{~m}$, and an average diameter of about $1 \mathrm{~m}$. They grow slowly, and have an average life-span of 60-200 years. Vitex doniana is popularly found growing in the tropical and sub tropical regions of the world and grows well in semi-arid tropical regions and humid tropical regions with seasonal rainfall ranging from $750-2000 \mathrm{~mm}$. they are commercially cultivated in various soil types of different origins that usually include alluvial soils and homestead gardens for its product. ${ }^{14}$ 
Caricaceae is the family Carica papaya Linnaeus (paw paw) belongs to, and it is an herbaceous perennial plant with rapid proliferation rate. ${ }^{15}$ Papaya has a short life span, but has a fruitage time of 20years. Papayas are hemaphodites i.e. possess both male and female parts, ${ }^{16}$ thus, they are self- fertilizing, ${ }^{17}$ and the commercially available papayas are the hermaphrodite trees that produce fruits that are pear shaped. The plant yields natural substance (Annonaceous acetogenins) in leaf barks and tissues of twig that has potent antitumor and pesticidal activities. ${ }^{18}$ Papayas are rich in self-defense compounds which confer a high level of immunity to attack by insects and to diseases. ${ }^{19}$ Peristrophe bicalyculata belongs to the family Acanthaceae and the genus Peristrophe. In Nigeria, the Hausas call it 'tubanin dawaki' translated as flour of the horse. In 'Serer' and 'Wolof' languages of Senegal, it is called 'buben' and 'môto' respectively. ${ }^{20}$ In the Indore district of India, the locally called 'Chotiharjori' ${ }^{21}$ They are found naturally in the tropical regions of Africa, in the Sahel part of the region of Mauritania, Niger and northern Nigeria as well as in India, Burma and Thailand. The herb possess anti-bacterial properties (tuberculostatic), and has proven to be effective in treating sprain, snake poison, fever, bone fracture, cold and cough and for ear and eye treatments, ${ }^{22}$ Furthermore, It is also used in the treatment of skin diseases, and serves as an antidote for metabolic diseases such as diabetics, hypercholesterolemia among others. ${ }^{23}$

\section{Materials and methods}

\section{Materials}

All the chemicals used for the extraction, phytochemical screening, reducing potential and DPPH assay were of analytical grade; DPPH radical was a product of Sigma-Aldriech, U.S.A.

\section{Sample collection and drying}

The fresh leaves of the investigated plants was harvested in July, 2017 from Faculty of Agriculture, Kogi State University Anyigba and were authenticated in the Department of Biological Sciences Herbarium, Ahmadu Bello University, Samaru-Zaria, where the plants were assigned voucher specimen numbers: 752, 753, 754 and 756 respectively for $O$. gratissimum, $V$. doniana, $C$. papaya and $P$. bicalyculata. The leaves were cleaned of sand particles, air-dried for 14 days. They were pulverized to powder and stored in air-tight containers in the refrigerator for subsequent use. These samples were brought out and allowed to assume room temperature prior to use for analysis.

\section{Methods}

\section{Preparation of the extracts}

Samples of the leaf powder of each plant $(50 \mathrm{~g}$ each) were macerated with $50 \mathrm{ml}$ of ethanol for $72 \mathrm{hrs}$ at room temperature. Each extract was filtered (Whatman No. 1 filter paper) and the residue re-extracted with the same solvent. The extracts were combined and concentrated in a rotary evaporator under reduced pressure to give the ethanol extract for phytochemical analysis and antioxidant- activity assay. ${ }^{24}$

\section{Phytochemical screening}

Chemical tests were carried out on the ethanol extracts and on the leaf powder using standard procedures of Trease and Evans, 1989; Harborne, 1973 and Sofowora, (1993); Odebedy and Sofowora, $(1978) .{ }^{25-28}$

\section{DPPH assay for antioxidant activity}

The ability of the extract to scavenge DPPH radical was determined according to Mensor et al. ${ }^{29}$ with little modification. $1.0 \mathrm{ml}$ of $0.3 \mathrm{~m} \mathrm{M}$ DPPH methanol solution was added to the solution of the extract or standard $(250 \mathrm{ug} / \mathrm{ml}, 2.5 \mathrm{ml})$ and allowed to react at room temperature for $30 \mathrm{mins}$. The absorbance of the resulting mixture was measured at $518 \mathrm{~nm}$ with spectrophotometer and converted to percentage antioxidant activity (AA \%). Methanol $(1.0 \mathrm{ml}$ plus extract solution $(2.5 \mathrm{ml})$ was used as a blank $1.0 \mathrm{ml}$ of $0.3 \mathrm{~m} \mathrm{MDPPH}$ plus methanol $(2.5 \mathrm{ml})$ was used as a negative control. Solution of ascorbic acid served as positive control. Antioxidant activity (AA) was calculated as percentage inhibition relative to control using the following equation. ${ }^{6}$

$\mathrm{AA} \%=$ Rcontrol - Rsample/Rcontrol X 100

Where:

Rcontrol $=$ absorbance of control.

Rsample $=$ absorbance with each sample.

$\mathrm{AA} \%=$ percentage of antioxidant activity.

Each extract (sample) at a particular dose or concentration was observed in triplicate.

\section{Determination of Reducing Potential}

Reducing potential was determined according to the method of Afolabi et al. ${ }^{30}$ The extract or standard $(100 \mu \mathrm{g} / \mathrm{ml}$ or $250 \mu \mathrm{mg} /$ $\mathrm{ml}$ respectively) was mixed with phosphate buffer and potassium ferricyanide. The mixture was incubated at $50^{\circ} \mathrm{C}$ for $20 \mathrm{mins}$. Trichloroacetic acid $(10 \%, 2.5 \mathrm{ml})$ was added to the mixture. A portion of the resulting mixture was mixed with ferric chloride $(\mathrm{FeCl} 3 ; 0.1 \%, 0.5 \mathrm{ml})$ and the absorbance measured at $700 \mathrm{~nm}$ using a Spectrophotometer. Higher absorbance of the reaction mixture indicates higher reductive potential.

\section{Statistical Analysis}

Results were analyzed using one way analysis of variance (ANOVA). Data was expressed as $\mathrm{Mean} \pm \mathrm{SEM}$, the differences between mean accepted as significant at $\mathrm{P}<0.05$ (ANOVA).

\section{Results}

The phytochemical screening of the plants investigated revealed the presence of flavonoids, saponins, C. glycosides, steroids, alkaloids, tannins, anthraquinones, terpenoids and carbonhydrates in the ethanol extracts of the plants (Table 1). From the DPPH assay carried out, the percentage antioxidant activities of the plants investigated were calculated to be $60.0 \pm 1.05,60.8 \pm 1.20,62.4 \pm 1.26$ and $75.7 \pm 2.60$ respectively for O. gratissimum, V. doniana, C. papaya and $P$. bicalyculata (Table 2). While the standards used were found to have percentage antioxidant activities of $86.7 \pm 1.08$ and $97.2 \pm 1.06$ respectively for ascorbic acid and $\alpha$-tocopherol (Table 2). All these were statistically significant at $\mathrm{P}<0.05$ (ANOVA) (Table 2). Also, the reducing potentials of the plants investigated were found to be proportional to the antioxidant activities of these plants (Table 2). These are respectively $0.8 \pm 0.02,1.0 \pm 0.07,1.2 \pm 0.06$ and $1.6 \pm 0.03$ for O. gratissimum, V. doniana, C. papaya and P. bicalyculata (Table 2). Ascorbic acid and $\alpha$-tocopherol as standard used showed reducing potentials of $1.8 \pm 0.02$ and $2.0 \pm 0.02$ respectively (Table 2 ). 
Table I Phytochemical Screening

\begin{tabular}{lllll}
\hline Phytochemicals & O. gratissimum & V. doniana & C. papaya & P. bicalyculata \\
\hline Flavonoids & ++ & +++ & +++ & +++ \\
Saponins & ++ & ++ & ++ & ++ \\
C.glycosides & ++ & +++ & +++ & +++ \\
Steriods & ++ & ++ & ++ & ++ \\
Alkaloids & + & ++ & ++ & + \\
Tanins & + & ++ & + & + \\
Anthraquinone & + & + & + & + \\
Terpenoids & ++ & + & ++ & + \\
Carbonhydrates & ++ & ++ & ++ & ++ \\
Renins & - & - & - & - \\
\hline
\end{tabular}

$+++=$ Abundant, $++=$ Moderate,$+=$ Present, - = Absent

Table 2 The antioxidant activities and reducing potentials of the investigated plants

\begin{tabular}{|c|c|c|c|c|}
\hline & $\begin{array}{l}\text { Antioxidant Activity } \\
\text { (AOA) }\end{array}$ & IC50 ( $\mu \mathrm{g} / \mathrm{ml})$ & $\begin{array}{l}\text { Percentage Antioxidant } \\
\text { Activity (\%AA) }\end{array}$ & $\begin{array}{l}\text { Reducing } \\
\text { Potential (RP) }\end{array}$ \\
\hline Control/blank (methanol) & 0.56 & $2.5 \mathrm{ml}$ & 0 & 0 \\
\hline O. gratissimum & 0.221 & 100 & $60.0 \pm 1.05^{*}$ & $0.8 \pm 0.02$ \\
\hline V. doniana & 0.218 & 120 & $60.8 \pm 1.20 *$ & $1.0 \pm 0.07$ \\
\hline C. papaya & 0.21 & 100 & $62.4 \pm 1.26^{* *}$ & $1.2 \pm 0.06$ \\
\hline P. bicalyculata & 0.122 & 180 & $75.7 \pm 2.60 * *$ & $1.6 \pm 0.06$ \\
\hline Ascorbic acid & 0.103 & 120 & $86.7 \pm 1.08^{* *}$ & $1.8 \pm 0.02$ \\
\hline$\alpha$-tocopherol & 0.017 & 50 & $97.2 \pm 1.06 * *$ & $2.0 \pm 0.02$ \\
\hline
\end{tabular}

** Represent significant at $\mathrm{P}<0.00 \mathrm{I}$; * significant at $\mathrm{P}<0.0 \mathrm{I}$ (ANOVA);AOA=Antioxidant activity, AA= Percentage antioxidant activity, RP= reducing potentials, IC50 $=50 \%$ inhibitory concentration. Experiments were carried out in triplicate and expressed as mean \pm standard error of mean (SEM).

\section{Discussion/conclusion}

Biologically active substances in plants such as flavonoids, terpernoids, saponins, tannins, anthraquinone, carbohydrate, glycosides, steroids, and alkaloids are responsible for the medicinal effects of plants in the management of diseases. These bioactive substances are popular for their anti-inflammatory, anti-diabetic, antimicrobial, anti-atherosclerotic and anti-carcinogenic properties. ${ }^{31}$ This study shows that the ethanol extracts of the leaves of O. gratissimum, $V$. doniana, C. papaya and $P$. bicalyculata tested positive for flavonoids, alkaloids, Cardiac glycosides, carbohydrates, anthraquinones, tannins, saponins, terpenoids and steroids. These compounds detected have been documented to have potent medicinal and therapeutic effects. ${ }^{32-34}$ and these findings are consistent with the previous works of Larson, 1988; Hudson, 1990; Hall and Cuppett, 1997. ${ }^{35-37}$

Futhermore, the result of the DPPH scavenging assay showed that the percentage antioxidant activity of $P$. bicalyculata was found to be the highest at $75.7 \pm 2.60 \%$ and this can be very much compared to the antioxidant activities of $\alpha$-tocopherol and ascorbic acids which were used as standards and obtained as $97.2 \pm 1.06 \%$ and $86.7 \pm 1.08 \%$ respectively. The percentage antioxidant activity of $P$. bicalyculata was found to be statistically significant at $\mathrm{P}=0.001$ (ANOVA). The high percentage antioxidant activity value obtained could be attributed to its abundance of flavonoids, Phenols and ascorbic acid which have been evaluated to be $1.72,1.86$ and $44.03 \mathrm{mg} / 100 \mathrm{~g}$ dry weight respectively. ${ }^{33}$ This is equally concurs with previous works of Nieto et al., (1993); Das and Pereira, (1990); and Foti et al., (1993). ${ }^{38-40}$

In addition, the percentage antioxidant activities of C. papaya, $V$. doniana and $O$. gratissimum were $62.4 \pm 1.26 \%, 60.8 \pm 1.20 \%$ and $60.8 \pm 1.20 \%$ respectively. These were significant at $\mathrm{P}<0.01$ (ANOVA). The values were comparable to the standards used. These concur with the works of Sathiyanaranan and Arulmozhi, (2007); Edeoga et al., 2005; Miliuaska et al., 2004. O. gratissimum, ${ }^{32,41,42}$ however, had the least percentage antioxidant activity of $60.0 \pm 1.05 \%$. This can also be compared to the percentage antioxidant activities of the $\alpha$-tocopherol and ascorbic acid used as standards (97.2 \pm 1.06 and $86.7 \pm 1.08$ respectively). This is statistically significant at $\mathrm{P}<0.05$ (ANOVA).

The reducing potential of these plants were noted to have a direct linear relationship with the percentage antioxidant activity, and this concurs with the work of Duan et al. ${ }^{43}$ These plants show potentials as likely sources for the development of new drugs, and the discoveries from this study have revealed these plants to be potent antioxidants. This property could be utilized in drug development, in the search of powerful antioxidants which are urgently needed to challenge free radicals in biological systems. It will consequently help to prevent 
ailments originating from free radicals. However, further study needs to be done to isolate and characterize the active principles in this plants. ${ }^{44}$

\section{Acknowledgments}

None.

\section{Conflict of interest}

The authors declare that there is no conflict of interest.

\section{References}

1. Ellinaim WM, Krucyyanalci Z, Kaapfak J. Investigation of the free radical scavenging activity of Cunkgo Kuoba L. Leaves. Fitoterapia. 2003;74(1-2):1-6.

2. Velioglu YS, Mazza G, Gao L. Antioxidant Activity and Total Phenolics in Selected Fruits, Vegetables, and Grain Products. J Agric Food Chem. 1998;46:4113-4117.

3. Cook NC, Samman S. Flavonoids chemistry: metabolism, cardiopoctive effects, and diatary sources. Nutr Biochem. 1996;7:66-76.

4. Huang MT, HO CT, Lee CY. Phenolic compounds in food and their effects on Health II. Antioxidants and cancer prevention, AC s symposium series 507. Washington, DC: American Chemical Society; 1992.

5. Sanchez-Moreno C. Methods used to evaluate the free radical scavenging activity in foods and biological systems. Food Sci Technol Int. 2002;8:121-137.

6. AL Saikhan MS, Howard LR, Millar JC. Antioxidant activity and total phenotics in different genotypes of potato (Solanum tuberosm, L). J Food Sci. 1995;60 (2):341-343.

7. Yen GC, Duh PD. Antioxidant activity of methanol extracts of peanut hulls from various cultivars. J Am old Chem Soc. 1995;72:(9):1065-1067.

8. Oomoh BD, Mazza G. Flavonoid and antioxidative activities in burckwheat. J Agric Food Chem. 1996;44(7):1746-1750.

9. Wang H, Cao GH, Prior RL. Total antioxidant capacity of fruits. J Agric Food. 1996;44:248-251.

10. Cao G, Sofic E, Prior RL. Antioxidant capacity of tea and common vegetable. J Agric Food Chem. 1996;44(11):3426-3431.

11. Amarowicz R, Wanasundara UN, Karamac M, et al. Antioxidant activity of ethanolic extract of mustard seed. Nahrung. 1996;40 (5):261-263.

12. Effraim KD, Jacks TW, Sadipo OA. Histopathological studies on the toxicity of Ocimum gratissimum leaf extract on some organs of rabbit. African Journal of Biomedical Research. 2003;6 (1):21-25.

13. Akinmoladun AC, Ibukun EO, Afor E, et al. Phytochemical constituent and antioxidant activity of extract from the leaves of Ocimum gratissimum. Science Research Essay. 2007;2(5):163-166.

14. FAO. Food and fruit bearing forest species from Eastern Africa, FAO Forestry Paper. 1983.

15. Dick G. Papaya; A tantalising taste of the Tropics. Maricopa County Master Gardener Volunteer information, University of Arizona Cooperative Extension. 2003.

16. Abdulazeez MA, Baba IA, Yenusa EZ, et al. Anti-trypanosomal effect of Peristrophe bicalyculata extracts on Trypanosoma brucei brucei-infected rats. Asian Pac J Trop Biomed. 2013;3(7):523-531.
17. Akinmoladum AC, Ibukun EO, Dan-Ologe IA. Phytochemical constituents and antioxidant properties of extracts from the leaves of Chromolaena odorata. Scientific Research and Essay. 2007;2(6):191-194.

18. Stajner D, De Mairno MM, Conadow BJ. Antixtidant and scavenger activities of cultivate and wild allium species Flto terapla 1999;74:1-60.

19. Peter RN. Pawpaw (Asimina). In: JN Moore, JR Ballington, editors. Genetic resources of temperate fruit and nut trees. Acta Hort. 1991;290:567-600.

20. Burkill H. The useful plants of west tropical Africa, Entry for Peristrophe bicalyculata (Retz) Nees [family ACANTHACEAE]. Vol. 1, Royal Botanical Gardens. 1985.

21. Dwivedi S. Ethnomedicinal uses of some plant species by ethnic and rural peoples of Indore district of Madhya Pradesh, India. 2008.

22. Rashmi G, Patel J, Prajapati H, et al. A Review on Peristrophe bicalyculata. Pharmacognosy J. 2010;(2)14.

23. Facino MR, Carinin N, Aldini G, et al. Antioxdant profile of a soy standardized extract in book abstract. 2000 years of national products research 680. 2000

24. AOAC. Official methods of analysis of the Association of Official Analytical Chemists, 15th ed. Association of Official Analytical Chemists, Arlington VA (1990). 2001:1058-1059.

25. Trease GE, Evans WC. Trease and Evans Pharmacognosy. 13th ed, Ballere tindal London; 1989.

26. Harborne JB. Phytochemical methods. London: Chapman and Hall Ltd; 1973:49-188

27. Sofowora A. Medicinal Plants and Traditional Medicine in Africa. Spetrum books; 1993.

28. Odebedy O, Sofowora. Phytochemical screening of Nigerian medicinal plants. Lloydia. 1978;41:41-234.

29. Mensor LL, Menezes FS, Leitao GG, et al. Screening of Brazilian plant extract for antioxidant activity by the use of DPPH free radical method. Phytother Res. 2001;15(2):127-130.

30. Ratnayake S, Rupprecht JK, Potter WM, et al. Evaluation of various parts of the pawpaw tree, Asiminatriloba (Annonaceae), as commercial source of the pesticidal annonaceous aceto genins. $J$ Econ Entomol. 1992;85(6):2353-2356.

31. Chukwuka KS, Ikheloa JO, Okonko IO, et al. The antimicrobial activities of some medicinal plants on Escherichia colias an agent of diarrhoea in livestock. Advan Appl Sci Res. 2011;2(4):37-48.

32. Edeogu HO, Okwu DE, Mbaebie BO. Phytochemical constituents of some Nigerian medicinal plants. African Journal of Biotehnology. 2005;4(7):685-688.

33. Okwu DE, Josiah C. Evaluation of the chemical composition of two Nigerian Medicinal plants. African Journal of Biotechnolgy. 2006;5(4):357-361.

34. Liu XS, Jiang YM, Chen F, et al. The relationship between the browning in the pericarp of Litchi (Litchi chinensis Sonn) fruit and 102 poly phenol oxidase, peroxidase, phenolics and their compartmentation. Acta Bot Austro sin. 1991;7:95-98.

35. Larson RA. The antiotidants of higher plants. Phytochermistry. 1988;27(4):969-978.

36. Hudson BJF. Ed. Food Antioxidant; Elsevier Applied Science London. 1990 . 
37. Hall CA, Cuppett SL. Structure activities of natural antioxidants in antioxdant methodology in vivo and in vitro concepts Aruma, O.L, cuppett SL., Eds: Aocs Press: Champsign il: 1997:2-29.

38. Nieto S, Garrido A, Sanhueza J, et al. A Flavonoids as stabilizers of fish oil. Alternative to synthetic antioxidant. J Ann Oil Chem Soc. 1993;70:777-778.

39. Das NP, Pereira TA. Effects of flavonoids on terminal autoxidation of palm oil: structure- activity relationship. J Agric food chem. 1990;44:497-501.

40. Foti M, Plattelli M, Barattas M. et al. Flavonoids coumarins and annamic acids as antioxidant in a micellar system structure - activity relationship. J Agric Food Chem. 1996;44(2):497-501.
41. Sathiyanarayanan L, Arulmozhi S. Mucuna pruriens Linn . A Comprehensive Review. Pharmacognosy Reviews. 2007;1(1):157-162.

42. Miliauska GPR, Venskuloris PR, Beek TA. Screening of radical scavenging activity of some Medicinal and aromatic plant extracts. Food Chem. 2004;85:231-237.

43. Duan X, Wu G, Jiang Y. Evaluation of the antioxidant properties of Litchi fruit phenolics in relation to pericarp browning prevention. Molecules. 2007;12(4):759-771.

44. Nia R, Paper DH, Easien EE, et al. Investigations into in vitro radical scavenging and in vivo anti inflamniatory potential of Tridax procumbens. Nig J physiological sciences. 2003;18:(1-2),39-43. 